\title{
Antidepressant and Antipsychotic-like Activity of the Ethanolic Extract of the Leaves of Maytenus macrocarpa
}

\author{
Tácuna-Calderón Ana Lucia ${ }^{1,2,3}$, Huaccho-Rojas Juan Jesus ${ }^{1,2,3}$, Zimic-Zare Carolina ${ }^{1,2}$, Pante-Medina Carlos ${ }^{1}$, \\ Salazar-Granara Alberto ${ }^{1,2,3 *}$
}

\section{Tácuna-Calderón Ana Lucia ${ }^{1,2,3}$, Huaccho-Rojas Juan Jesus ${ }^{1,2,3}$, Zimic-Zare Carolina ${ }^{1,2}$, Pante-Medina Carlos ${ }^{1}$, Salazar-Granara Alberto ${ }^{1,2,3 *}$}

\begin{abstract}
${ }^{1}$ Universidad de San Martin de Porres, Facultad de Medicina Humana, Centro de Investigación de Medicina Tradicional y Farmacología, Lima, PERU.
\end{abstract}

2Universidad Peruana Cayetano Heredia, Facultad de Ciencias y Filosofía, Sección Bioquímica, Biología molecular y Farmacología, Lima, PERU.

${ }^{3}$ Sociedad Peruana de Farmacologia y Terapéutica Experimental (SOPFARTEX), Lima, PERU.

Correspondence

Salazar Granara Alberto

Alameda del Corregidor №1517 Urb. Los Sirius III Etapa - La Molina

Phone no : +511-3652300 / 151

E-mail: asalazarg@usmp.pe

\section{History}

- Submission Date: 21-04-2018;

- Review completed: 28-06-2018;

- Accepted Date: 07-09-2018

DOI : 10.5530/pj.2018.6s.6

Article Available online http://www.phcogj.com/v10/i6s

\section{Copyright}

(C) 2018 Phcog.Net. This is an openaccess article distributed under the terms of the Creative Commons Attribution 4.0 International license.

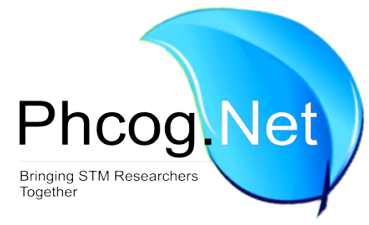

\begin{abstract}
Introduction: Maytenus macrocarpa (Chuchuhuasi) is an Amazonian Peruvian traditional plant, traditionally used as anti-inflammatory, antipyretic, antihemorrhagic and antidiarrheic agent. Also, chuchuhuasi is known as a master plant, attributing to it properties in the central nervous system. In addition, depression is a disorder of the mood that cause disability to millions of people around the world. For this reason, the aim of this study was to determinate the antidepressant and antipsychotic-like activity of the ethanolic extract of Maytenus macrocarpa. Methods: It was used the ethanolic extract of the leaves of Maytenus macrocarpa (EELMM) in female mice at the experimental model of the Forced Swim Test described by Porsolt. As control, it was used distillate water, fluoxetine and haloperidol. Results: The immobility time of the groups of EELMM has a mean of $38.26 \pm 21.57,84.32 \pm 26.68$ and $32.17 \pm 25.55$ for the doses of 750,1000 and $1250 \mathrm{mg} / \mathrm{Kg}$ respectively; and the immobility time had a median of 7.5 [4.07 - 20.3] and $20.93 \pm[17.63-23.75]$ for the doses of $500 \mathrm{mg} / \mathrm{Kg}$ and $1500 \mathrm{mg} / \mathrm{Kg}$. It was seen a positive dose-response between the dose of 500 to $1000 \mathrm{mg} / \mathrm{Kg}$ (Pearson correlation of $r=0.8339$ and $R=0.6954$ ) and a negative dose-response between the dose of 1000 to $1500 \mathrm{mg} / \mathrm{Kg}$. (Pearson correlation of $r=-0.7590$ and $R=0.5760$ ). Conclusion: It was demonstrated the antidepressant-like activity of the ethanolic extract of the leaves of Maytenus macrocarpa with a dose of $500 \mathrm{mg} / \mathrm{kg}$ and an antipsychotic-like activity with a dose of $1000 \mathrm{mg} / \mathrm{kg}$.
\end{abstract}

Key words: Chuchuhuasi, Depression, Forced swim test, Haloperidol, Fluoxetine.

\section{INTRODUCTION}

The medicinal plants are ancestrally used, they belong to the therapies with medication according to the document of Strategies about Traditional Medicine 20142023 of the World Health Organization. Also, at the same document, it is urged the promotion of research on traditional medicine with the purpose of achieve its rational and safe use. ${ }^{1}$

One of the native Peruvian medicinal plants is "chuchuhuasi", whose scientific name is Maytenus macrocarpa (Ruiz and Pav.) Briq. ${ }^{2}$ which is one of the 4400 peruvian species of medicinal plants. ${ }^{3}$ Chuchuhuasi has a big tree from the Celastraceae family and is native of the amazon. Its branches are whorled and its leaves coriaceous, oblong-lanceolate or elliptical, acuminate, emarginated and glossy in the beam that have 10 to 20 $\mathrm{cm}$. long and it has axillary inflorescence. It is traditionally used for its analgesic, antipyretic, antidiarrheic and antihemorrhagic at postpartum properties among others. ${ }^{2,4-5}$ Also, Chuchuhuasi is part of a selected group of Peruvian plants named master plants, as ayahuasca, coca, among other. These plants are used to heal a person by taking it to high levels of the consciousness, coming into contact with the spiritual world; this is why these plants are probably attributed effects at cen- tral nervous systems as psychotropic and hallucinogens. $^{6-9}$

Laboratory studies in rodents have confirmed biological effects of Maytenus macrocarpa, having reported intestinal stimulant activity, analgesic activity, bradycardia, decrease on the p-wave voltage at the electrocardiogram and alteration of sperm morphology. ${ }^{10-13}$ Also, there is a study in rodents of the bark of Maytenus macrocarpa in which it was demonstrated neuroleptic effect, sedation and stereotypes, on the other hand, in another study of the root of Maytenus obtusifolia it was demonstrated the potential depressant effect over the central nervous system..$^{14-15}$

Depression is a disorder of the mood that causes disability and affects more than 300 million people around the world. In Peru the prevalence of depression is at the range of $18,2 \%$ to $21,4 \%$. The treatment of depression involves the use of antidepressant drugs, that currently have variable efficacy and adherence due to their adverse effects and pharmacology interactions; situation that promotes the search for new antidepressant. ${ }^{16-18}$ There is an experimental model in rodents to evaluate the antidepressant and 
neuroleptic effect of chemical substance, which is called Forced Swim Test or Porsolt's test. ${ }^{19-21}$ Many drugs were validated using this test, like fluoxetine, amitriptyline and haloperidol. ${ }^{22-23}$ For this reason, this study was centered on exploring the antidepressant or antipsychotic-like activity of the ethanolic extract of the leaves of Maytenus macrocarpa in a model of forced swim in rodents.

\section{MATERIALS AND METHODS}

\section{Type of Study, Space and temporality}

It was a quasi-experimental double-blind study that was conducted at Traditional Medicine and Pharmacology Research Center.

\section{Vegetal Sample}

Leaves of Maytenus macrocarpa was collected in the region of Madre de Dios (Sur-east, Peru). The plant was identified by a specialist from the Research Center. Voucher specimens are deposited at the Herbarium Vargas CUZ from the Universidad Nacional San Antonio Abad del Cuzco, numbers 3547 and 3653.

\section{Preparation of the Ethanolic extract of the leaves of Maytenus macrocarpa (EELMM)}

The ethanolic extract was prepared with the following methodology: ${ }^{24}$ the leaves collected were macerated for one week with ethanol at $70 \%$. Then the mixture was filtrated and reduced at the rotavapor. The resulting was dried at the stove for $48 \mathrm{~h}$ and then stored at hermetic containers in the refrigerator for its future use. The final product was dissolved with distillate water at appropriate proportions for an administration volume less than $0.30 \mathrm{~mL}$ of the extract.

\section{Animal Sample}

We used 88 female albino mice of $\mathrm{BALB} / \mathrm{c}$ strain, with an average weight of $30 \mathrm{~g}$ from the vivarium of the National Institute of Health of Peru.

The mice were prepared at the vivarium with the following conditions: a distribution of two mice per cage, cleaning cycles twice per day, a balanced diet, water at libitum, room temperature of $22^{\circ} \mathrm{C}\left(+/-1^{\circ} \mathrm{C}\right)$ or $71.6^{\circ} \mathrm{F}$, humidity between $50-70 \%$, light/darkness cycles of $12 \mathrm{~h}$ and noise levels less than $70 \mathrm{db}$.

\section{Chemistry Sample}

Il was used Fluoxetine at tables of 20mg with S.R. NG-2276, Lab AC FARMA S.A., Series: 1060542, Exp.: 06-2015; Haloperidol ampoule of $5 \mathrm{mg} / 1 \mathrm{~mL}$ with S.R. Peru EG-674, Lab SANDERSON S.A., Series Nº5FL2479, Exp.: 11-2016; and distillate water.

\section{Forced Swim Test in mice}

This test was previously described by Porsolt and col..$^{22}$ The mice were carried to the laboratory two hours before the experimental. It was used transparent cylinders filled with water with $10 \mathrm{~cm}$. depth; the temperature was set to $22^{\circ} \mathrm{C}\left(+/-2^{\circ} \mathrm{C}\right)$. The cylinders were separated with dark panels. Sixty minutes before the swim, mice were administrated the respective substance orally. We placed to swim one mouse per cylinder at two cylinders simultaneously then we recorded six minutes of swimming, the first two of adaptation to the water and at the last four minutes was counted the immobility time.

\section{Design of experimental groups}

We used 11 experimental groups with eight mice in each group. Group 1, was the control and didn't received any substance; group 2 was placebo and received $0.1 \mathrm{ml}$ of distillate water per each $10 \mathrm{~g}$ of corporeal weight. The rest of the groups received the following substances: group 3, fluoxetine $40 \mathrm{mg} / \mathrm{Kg}$; group 4, fluoxetine $80 \mathrm{mg} / \mathrm{Kg}$; group 5, haloperidol $1 \mathrm{mg} / \mathrm{Kg}$; group 6, haloperidol 3mg/Kg; group 7, EELMM $500 \mathrm{mg} / \mathrm{Kg}$; group 8, EELMM 750mg/Kg; group 9, EELMM 1000mg/Kg; group 10, EELMM 1250mg/Kg; and group 11, EELMM 1500mg/Kg.

\section{Blind and control system}

A double-blind system was applied in which the person that administrated the solutions and observed the reactions, didn't know the origin of these solutions. ${ }^{25}$ Noise levels, humidity, room temperature and swimming tanks were monitored using VWR hygrometer model Thomas Traceable $^{\infty}$ Digital Humidity/Temperature Meter 35519-045 with a capacity to measure humidity from $60 \%$ to $82 \%$ and a temperature range from $5^{\circ} \mathrm{C}$ to $34^{\circ} \mathrm{C}$, a sound level digital indicator Radio Shack 33-2055, able to measure from 60 to $120 \mathrm{Db}$, a insertion thermometer for water temperature of the forced swimming test, manufactured by Isolab with measurement capabilities from $-50^{\circ} \mathrm{C}$ to $300^{\circ} \mathrm{C}$, two fan heaters to maintain a stable temperature of the room, brand NF15C $1500 \mathrm{~W}$ Imaco with 2 heat intensities: 1000-2000W for an area of $15 \mathrm{~m}^{2}$. Research assistants were trained to explore physical manifestations using the Pharmacology Lab Virtual Software ${ }^{26}$ and Microlabs ${ }^{27}$ and by an in vivo pilot.

\section{Ethics aspect of the research}

The study was approved by the Research Institute of the FMH-USMP following the International Guiding Principles for Biomedical Research Involving Animals ${ }^{28}$ and the Declaration of the Use of Animals in Biomedical Research. ${ }^{29}$

\section{Statistical Analysis}

The immobility time was described as mean, median, standard deviation and interquartile range. It was applied the statistical test of Shapiro-Wilks to evaluate a normal distribution of the data, Kruskal-Wallis to evaluate difference between the experimental groups, Dunn's Multiple Comparison as a post hoc test and Pearson Correlation to set the curve dose-response of the EELMM. The Statistical significance was set for a $p$ value $<0.05$ with a confidence interval of $95 \%$ (CI95\%). It was used as informatics support Microsoft Excel 2010 and Graph Pad Prism 5.01 version.

\section{RESULTS}

The immobility time of the groups of EELMM was $38.26 \pm 21.57,84.32$ \pm 26.68 and $32.17 \pm 25.55$ for the doses of 750,1000 and $1250 \mathrm{mg} / \mathrm{Kg}$ respectively. In the groups that didn't have normal distribution the immobility time had a median of $7.5[4.07-20.3]$ and $20.93 \pm[17.63-$ 23.75] for the doses of $500 \mathrm{mg} / \mathrm{Kg}$ and $1500 \mathrm{mg} / \mathrm{Kg}$. (Table 1)

The Kruskal-Wallis Test, got a $\mathrm{p}<0.0001$ with a CI95\%. Later the groups were analyzed with the Dunn's multiple comparisons Test, finding a $\mathrm{p}<0.05$ for the following pairs of groups: control vs Fluoxetine, Control vs EELMM 500 mg/kg, Placebo vs Fluoxetine, Fluoxetine vs Haloperidol, Fluoxetine vs EELMM $1000 \mathrm{mg} / \mathrm{kg}$, Haloperidol vs EELMM $500 \mathrm{mg} / \mathrm{kg}$, EELMM $500 \mathrm{mg} / \mathrm{kg}$ vs EELMM $1000 \mathrm{mg} / \mathrm{kg}$. For the rest of combinations, the Dunn's multiple comparisons Test got a p > 0.05 (CI95\%) (Figure 1) Pearson correlation showed a positive correlation between doses of 500 to $1000 \mathrm{mg} / \mathrm{kg}$ with an $\mathrm{r}=0.8339$ and $\mathrm{R}=0.6954$ with a CI95\% (0.6689 a 0.9206 ) and a $\mathrm{p}<0.0001$ (Figure 2). On the other hand, it was obtained a negative correlation between doses of 1000 and $1500 \mathrm{mg} / \mathrm{Kg}$ with an $\mathrm{r}=-0.7590$ and $\mathrm{R}=0.5760$ with a CI of $95 \%(-0.8879 \mathrm{a}-0.5196)$ and $\mathrm{a}$ $\mathrm{p}<0.001$. (Figure 3)

\section{DISCUSSION}

In this study, it was observed that extreme doses of 500 and $1500 \mathrm{mg} / \mathrm{Kg}$ of EELMM an effect similar to it was obtained with fluoxetine, while a 
Table 1: Descriptive data of the immobility time of the experimental groups.

\begin{tabular}{cccc}
\hline Substance $(\mathrm{mg} / \mathrm{kg})$ & Mean \pm SD $^{*}$ & $\begin{array}{c}\text { Normal } \\
\text { Distribution } \\
\text { (SW test) }\end{array}$ & Median [IQR] $^{*}$ \\
\hline Blanco & $108.5 \pm 24.46$ & Yes & $103.4[83.75-134.7]$ \\
Placebo & $62.22 \pm 19.95$ & Yes & $57.04[48.45-77.55]$ \\
Fluoxetine 40 & $10.16 \pm 11.05$ & No & $6.02[2.93-17.86]$ \\
Fluoxetine 80 & $5.08 \pm 8.98$ & No & $1[0-6.5]$ \\
Haloperidol 1 & $113.53 \pm 51.16$ & Yes & $111.3[79.72-163.7]$ \\
Haloperidol 3 & $109.90 \pm 27.68$ & Yes & $107.9[87.47-127.6]$ \\
M. macrocarpa 500 & $12.15 \pm 11.45$ & No & $7.5[4.07-20.3]$ \\
M. macrocarpa 750 & $38.26 \pm 21.57$ & Yes & $38.84 \pm[19-54.29]$ \\
M. macrocarpa 1000 & $84.32 \pm 26.68$ & Yes & $84.34 \pm[64.20-102.3]$ \\
M. macrocarpa 1250 & $32.17 \pm 25.55$ & Yes & $23.0 \pm[9-61.13]$ \\
M. macrocarpa 1500 & $22.59 \pm 8.12$ & No & $20.93 \pm[17.63-23.75]$ \\
\hline
\end{tabular}

*SD: Standard deviation. SW test=Shapiro Wilks normality test. IQR=Interquartile range.

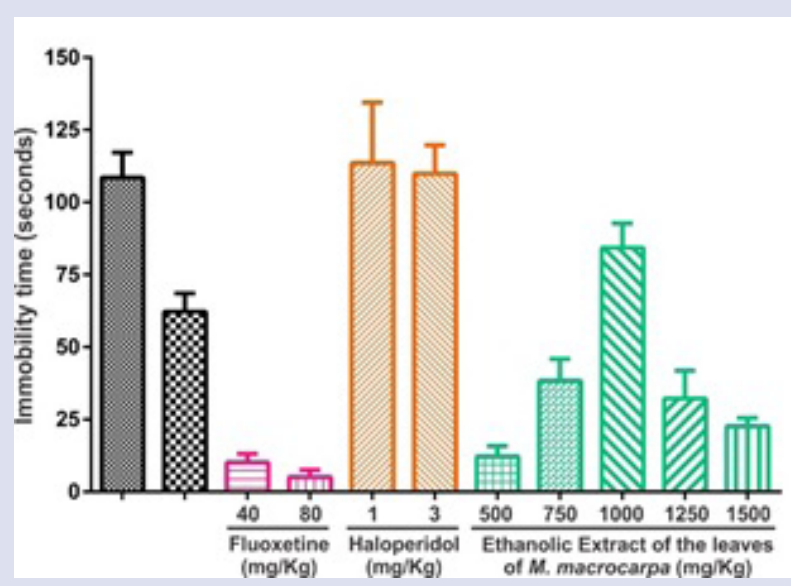

Figure 1: Immobility time of the Ethanolic Extract of the leaves of M. macrocarpa and control groups.

dose of $1000 \mathrm{mg} / \mathrm{kg}$ of EELMM the effect was similar to haloperidol. These results contrast with those obtained by a study conducted with an ethanolic extract of the bark of $M$. macrocarpa that evaluated the antipsychotic effect obtaining a negative dose-response curve, resulting that with the mayor dose of $1000 \mathrm{mg} / \mathrm{kg}$ the effect was similar to fluoxetine. ${ }^{14}$ Also, at the study conducted with chloroform extract of the root of Maytenus obtusifolia MART, it was evidenced the neuroleptic activity at three experimental models with a unique dose of $125 \mathrm{mg} / \mathrm{kg}$, that differed with our study in which the lowest dose was similar to fluoxetine. ${ }^{15}$ These changes could be to the multiple doses evaluation in a unique experimental model, that allowed us observed the dose- response curve of the EELMM. These results could expand the evidence of the Central Nervous system activity of the Maytenus genus and at the same time, the variability of this activity depending of the part of the plant that is use. (bark, leaves, root). ${ }^{30}$

The fluoxetine is a drug of the Selective Inhibitors of Serotonin Recaption family, whose site of action its located at the Synaptic cleft producing an increased and prolonged serotonergic transmission by stimulating many postsynaptic receptors. ${ }^{31}$ Then, the antidepressant effect observed could

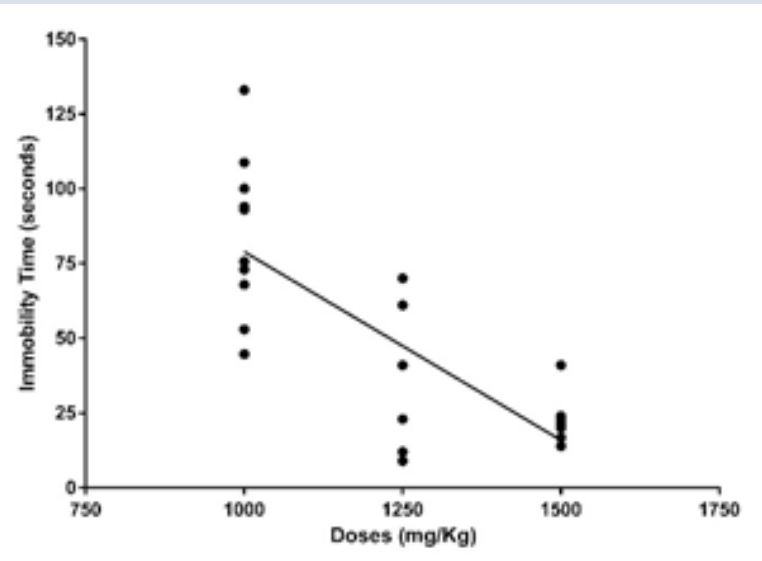

Figure 3: Doses-response of the immobility time of the Ethanolic Extract of the leaves of M. macrocarpa at doses of 1000 to $1500 \mathrm{mg} / \mathrm{Kg}$.

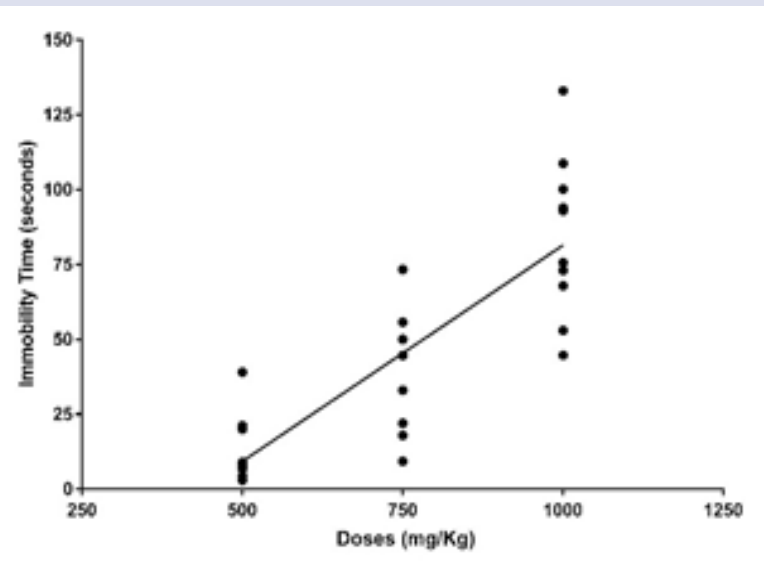

Figure 2: Doses-response of the immobility time of the Ethanolic Extract of the leaves of M. macrocarpa at doses of 500 to $1000 \mathrm{mg} / \mathrm{Kg}$.

be due to secondary metabolites present in the Maytenus macrocarpa's leaves, of which the most abundant are terpenes, among them the sesquiterpenes and terpenoids such as lupeol, friedeline and epifriedelinol, ${ }^{32}$ which have been identified with antioxidant, anti-inflammatory, antinociceptive and antitumor properties, which will result in a neuroprotection effect of the central nervous system. Also, is was found that lupeol has medium activity of inhibition of the acetylcholinesterase, increasing the amount of this neurotransmitter and stimulating the secretion of other neurotransmitters such as catecholamines. ${ }^{33-35}$

In addition, the presence of other secondary metabolites as polyphenols ${ }^{36}$ could support the antidepressant effect, because a study of polyphenols isolated front green tea demonstrated that these metabolites have an antidepressant effect (in the forced swim test and the tail suspension test) and that this effect was probably for and inhibition of the hypothalamichypophysis - adrenal axis by decreasing cortisol and ACTH levels. ${ }^{37}$ On the other hand, the probably antipsychotic effect found at dose of $1000 \mathrm{mg} / \mathrm{kg}$ of EELMM could be to the action of a secondary metabolite unidentified yet, such the case of another plant of the family, the Maytenus obtusifolia MART and its metabolite linalool, ${ }^{38}$ whose may decreased the 
release of glutamate potassium dependent without the intervention of the basal release of glutamate, acting specifically at ionotropic receptor AMPA or NMDA type, which is the reason it would have a neuroleptic and anticonvulsant effect. ${ }^{39-41}$

The dual effect observed in our study according to the dose-response curve suggest us, that one of the secondary metabolites could have a selective affinity receptor dose-dependent, such is the case of the adrenaline that at low dose have major affinity to beta receptors and with higher doses major affinity to alfa adrenergic receptors. ${ }^{42}$ Nevertheless, another theory to the dual effect, could be that recently it was described as part of the physiopathology of the depression and schizophrenia an increase of the proinflammatory component at the Central Nervous System, so that the application of anti-inflammatory therapies (effect attributed to metabolites of the EELMM) could be beneficial in this kind of diseases. ${ }^{43-44}$

\section{Limitations}

The main limitation of our study was that we couldn't determinate the mechanism or specific place of action for the antidepressant and antipsychotic effects because there are a plenty of secondary metabolites present in Maytenus macrocarpa. For future studies, we suggest to evaluate the effect of each metabolite in the Central Nervous System as well as the specific mechanism of action by which these metabolites act.

\section{CONCLUSION}

It was demonstrated a dual effect dose-dependent of the ethanolic extract of the leaves of Maytenus macrocarpa with a positive correlation between the dose of 500 to $1000 \mathrm{mg} / \mathrm{kg}$ and a negative correlation between the dose of 1000 to $1500 \mathrm{mg} / \mathrm{kg}$. It was demonstrated the antidepressant-like activity of the ethanolic extract of the leaves of Maytenus macrocarpa with a dose of $500 \mathrm{mg} / \mathrm{kg}$ and an antipsychotic-like activity with a dose of $1000 \mathrm{mg} / \mathrm{kg}$.

\section{ACKNOWLEDGEMENT}

We want to thank the dean of our Medical School, Dr. Lizaraso Caparó; the past director, Dr. Castañeda; and the actual director of our Research Institute, Dr. Lizaraso Soto for their support to complete the present research work. Also, we are thankful to Professor Alvarado and Professor Loja for their help with the extract preparation and Botanical identification of the plant.

\section{CONFLICT OF INTEREST}

The authors declared no conflict of interest.

\section{ABBREVIATIONS}

EELMM: Ethanolic Extract of the leaves of Maytenus macrocarpa; SD: Standard deviation; SW test: Shapiro Wilks normality test; IQR: Interquartile range.

\section{SUMMARY}

The aim of the study was to determinate de antidepressant or antipsychotic-like effect of the ethanolic extract of the leave of Maytenus macrocarpa. For this reason, we used 88 albino female mice, at the experimental model of Porsolt, the Forced Swim Test. We used eleven experimental groups (one for blanco, one for distillated water, two for fluoxetine, two for haloperidol and five groups with the EELMM). The result was that at the dose of $500 \mathrm{mg} / \mathrm{Kg}$ of EELMM, we obtained an antidepressantlike effect and at the dose of $1000 \mathrm{mg} / \mathrm{Kg}$ of EELMM we observed an antipsychotic-like effect.

\section{REFERENCE}

1. World Health Organization. WHO Traditional Medicine Strategy 2014-2023 [Internet]. 1st ed. Hong Kong: Word Health Organization; 2014 [cited 2017 Dec 9]. Available from: http://apps.who.int/medicinedocs/documents/s21201en/ s21201en.pdf

2. Mejía K, Rengifo E. Plantas medicinales de uso popular en la Amazonía Peruana. 2nd ed. Lima: Agencia Española de Cooperación Internacional. 2000;286.

3. MINAGRI. Diversidad de especies [Internet]. Minagri.gob.pe. 2015 [cited 2017 Dec 9]. Available from: http://www.minagri.gob.pe/portal/objetivos/47-sectoragrario/recurso-biodiversidad/345-diversidad-de-especies

4. Desmarchelier C, Witting-Schaus F. Sixty medicinal plants from the Peruvian Amazon: Ecology, ethnomedicine and bioactivity. 1st ed. Lima: Gráfica Bellido. 2000;270

5. Salazar A, Loja B, Rabanal A, Mestanza S, Heringman K, Pinedo D, et al. Comparación de los usos del Chuchuhuasi (Maytenus macrocarpa) entre indígenas Bora-Bora de Loreto y chamanes de Lima (Perú). Rev Fitoter. 2013;13(1):149-57.

6. Graña León D. Concepciones sobre la salud en un grupo de curanderos de la selva peruana. Thesis, Lima: Pontificia Universidad Católica del Perú. 2013.

7. Rojas-Bolívar D. Ayahuasca: el encuentro de dos paradigmas. Rev Neuropsiquiatr. 2014;77(1):40-7.

8. Henman AR. La coca como planta maestra: Reforma y nueva ética. Debate Agrar. 2005;267-78.

9. Tournon J, et al. Etnobotánica de los shipibo-konibo. In: Horák M, editor. Etnobotánica y fitotarapia en América. $1^{\text {st }}$. ed. República Checa. 2015;110-62.

10. Alosilla Uscamaita A, Chaves Palomares F, Ascaño Ramírez A, Cornejo Liñán M, Huamán Castro C, Medina Morales J, et al. Acción del extracto etanólico de las hojas de Maytenus macrocarpa (Ruiz. Pav.) Briq. "chuchuhuasi" sobre la motilidad intestinal. Horiz Méd. 2013;13(2):6-11.

11. Huaccho Rojas JJ, Cavero Aguilar ES, Quezada Rojas MA, Lara Paredes AM, Lluen Escobar SE, Paragulla Bocángel AA, et al. Efectos sobre la temperatura, frecuencia respiratoria, frecuencia cardiaca y electrocardiograma de Maytenus macrocarpa (Ruiz and Pav.) Briq. (chuchuhuasi). Rev Cuba Plantas Med. 2012(1);17:233-43.

12. Robles-Pizarro V, Tarqui-Cabrera L, Rodríguez-Collazos N, Morales-Chau A, De La Cruz-Manyari J, Ríos-Melgar $\mathrm{K}$, et al. Efecto antinociceptivo del extracto etanólico de las hojas de Maytenus macrocarpa (Ruiz and Pav.) Briq. "chuchuhuasi" mediante la prueba de contorsiones abdominales en ratones. Horiz Méd. 2014;14(1):6-10.

13. Acosta LG, Vásquez J, Núñez V, Pino J, Shiga B. Efecto de Maytenus macrocarpa "Chuchuhuasi" en el sistema reproductor masculino del ratón (Mus musculus). Rev Peru Biol. 2014;20(3):223-6.

14. Zambrano Santoyo C, Zúñiga Espinoza L, Zanabria Puente R, Zegarra Sánchez J Zaga Quispe N, Pante Medina C, et al. Antipsychotic and behavior effect of the ethanolic extract from the bark of Maytenus macrocarpa (Ruiz and Pav.) Briq.in mice. Pharmacogn Commun. 2015;5(4):244-9.

15. de Sousa DP, de Almeida RN. Neuroleptic-like properties of the chloroform extract of Maytenus obtusifolia MART. roots. Biol Pharm Bull. 2005;28(2):224-5.

16. American Psychiatric Association. Diagnostic and statistical manual of mental disorders (DSM-5®). American Psychiatric Pub. 2013.

17. Depression [Internet]. World Health Organization. 2018 [cited 2017 Sep 10] Available from: http://www.who.int/news-room/fact-sheets/detail/depression

18. Rondon MB. Salud mental: un problema de salud pública en el Perú. Rev Peru Med Exp Salud Pública. 2006;23(4):237-8.

19. Yamaura K, Nakayama N, Shimada M, Bi Y, Fukata H, Ueno K. Antidepressantlike effects of young green barley leaf (Hordeum vulgare L.) in the mouse forced swimming test. Phcog Res. 2012;4(1):22-6.

20. Agrawal A, Bavaskar S, Salunkhe P, Manyar N, Kale D, Kawtikwar P. Beta vulgaris: A dearth of antidepressant activity in mice. J Pharm Negative Results 2010;1(2):55-7.

21. Reddy AJ, Handu SS, Dubey AK, Mediratta PK, Shukla R, Ahmed QM. Effect of Musa sapientum stem extract on animal models of depression. Phoog Res 2016;8(4):249-52

22. Castagné $V$, Moser P, Roux S, Porsolt RD. Rodent models of depression: Forced swim and tail suspension behavioral despair tests in rats and mice. Curr Protoc Neurosci. 2011;(SUPPL.55):1-14

23. Mahesh R, Viyogi S, Pandey DK, Yadav S. Evaluation of anti-depressant and analgesic- like activity of ondansetron in rodents model of co-morbid pain and depression. Indian J Pharm Educ Res. 2010;44(2):160-70.

24. Márquez Vizcaíno RL, De La Rosa Torres C, Mercado Perez A. Actividad antifúngica del extracto total en etanol de las Hojas frescas de Pedilanthus tithymaloides L Poit (Ultimorrial). Sci Tech. 2007;13(33):155-9.

25. Galduf J, Gallego C, Escrivá J, Montserrat V. Ensayos clínicos: Elaboración de una lista-guía para la valoración de protocolos. Farm Hosp. 1995;19(1):17-23.

26. Mujica J, Pulliti Y. Procesamiento de señales in vivo, edición audiovisual y creación de un prototipo de software educativo para simulación de experimentos en farmacología Thesis, Lima: Universidad de San Martin de Porres. 2009.

27. van Wilgenburg H. Microlabs for Pharmacologists [Internet]. [cited 2017 Dec 
16]. Available from: https://norecopa.no/norina/microlabs-for-pharmacologists

28. ICLAS C. International Guiding Principles for Biomedical Research Involving Animals. 2013;1-4

29. World Medical Association. Statement on Animal Use in Biomedical Research. In Hong Kong. 1989.

30. Veloso CC, Soares GL, Perez AC, Rodrigues VG, Silva FC. Pharmacologica potential of maytenus species and isolated constituents, especially tingenone, for treatment of painful inflammatory diseases. Braz J Pharmacogn. 2017;27(4):533-40

31. James M. O'Donnell, Richard C. Shelton. Drug Therapy of Depression and Anxiety Disorders. In: Laurence L. Brunton, editor. Goodman and Gilman's: The pharmacological Basis of Therapeutics. 12a. Chicago: McGraw-Hill. 2012;2035.

32. Chávez H, Callo N, Estévez-Braun A, Ravelo AG, González AG. Sesquiterpene polyol esters from the leaves of Maytenus macrocarpa. J Nat Prod. 1999;62(11):1576-7.

33. Gallo M, Miranda B, Sarachine J. Biological Activities of Lupeol. Int J Biomed Pharm Sci. 2009;3:46-66.

34. Saleem M. Lupeol, A Novel Anti-inflammatory and Anti-cancer Dietary Triterpene. Cancer Lett. 2009;285(2):109-15.

35. Gamboa S, Buitrago G, Salama A. Actividad antinociceptiva de triterpenos aislados de Clusia ellipticifolia. Rev Colomb Cienc Quím-Farm. 2004;33(2):156-62.

36. Pérez Quintana M, Silva L, Radice M, Bravo L, Sánchez J, Riofrio A. Polyphenols extracts from (Theobroma cacao) and Chuchuhuaso (Maytenus macrocarpa) as possible natural Amazonian antioxidant. In: Proceedings of MOL2NET 2017, International Conference on Multidisciplinary Sciences, 3rd ed [Internet]. 2017. p. 4623. Available from: http://sciforum.net/conference/mol2net-03/paper/4623

37. Zhu WL, Shi HS, Wei YM, Wang SJ, Sun CY, Ding ZB, et al. Green tea polyphenols produce antidepressant-like effects in adult mice. Pharmacol Res. 2012;65(1):74-80.

38. de Medeiros VM, Sena Filho JG, Lucio ASSC, Tavares JF, Maia GLA, Lima EE de $\mathrm{O}$, et al. Chemical Composition and Antimicrobial Activity of Essential Oi from Leaves of Maytenus obtusifolia Mart. (Celastraceae). J Essent Oil Res. 2010;22(5):466-9.

39. Batista PA, Werner MF de P, Oliveira EC, Burgos L, Pereira P, Brum LF da S, et al. Evidence for the involvement of ionotropic glutamatergic receptors on the antinociceptive effect of (-)-linalool in mice. Neurosci Lett. 2008;440(3):299-303.

40. Elisabetsky E, Brum LFS, Souza DO. Anticonvulsant properties of linalool in glutamate-related seizure models. Phytomedicine. 1999;6(2):107-13.

41. Silva Brum LF, Elisabetsky E, Souza DO. Effects of linalool on glutamate realease and uptake in mouse cortical synaptosomes. Neurochem Res. 2001;26(3):191-

42. Thomas Westfall, David Westfall. Adrenergic Agonists and Antagonists. In: Laurence Brunton, editor. Goodman and Gilman's: The pharmacological Basis of Therapeutics. 12 $2^{\text {th }}$ ed. Chicago: McGraw-Hill. 2012;2035.

43. Naeem S, Najam R, Alam N. Antidepressant Effect of Diclofenac against Experimental Parkinson's Rat Model. Am J Pharmacol Sci. 2015;3(3):74-8.

44. Swardfager W, Rosenblat JD, Benlamri M, McIntyre RS. Mapping inflammation onto mood: Inflammatory mediators of anhedonia. Neurosci Biobehav Rev. 2016;64:148-66.

Cite this article: Tácuna-Calderón AL, Huaccho-Rojas JJ, Zimic-Zare C, Pante-Medina C, Salazar-Granara A. Antidepressant and Antipsychotic-like Activity of the Ethanolic Extract of the Leaves of Maytenus macrocarpa. Pharmacog J. 2018;10(6)Suppl:s33-s37. 